\title{
Importance of intraocular pressure measurement at 6:00 a.m. in bed and in darkness in suspected and glaucomatous patients
}

\author{
A importância da medida da pressão intraocular às 6 horas no leito \\ e no escuro em suspeitos e portadores de glaucoma
}

Sebastião Cronemberger ${ }^{1}$, Andréa Cristiane Lopes da Silva ${ }^{2}$, Nassim Calixto ${ }^{1}$

\section{ABSTRACT}

Purpose: To assess the importance of intraocular pressure measurement obtained at 6:00 a.m. in bed and darkness for the diagnosis and intraocular pressure control of primary open-angle glaucoma.

Methods: Retrospective analysis of the daily curve of intraocular pressure of suspects and glaucomatous patients under treatment. Suspects were classified as intraocular pressure values ranging from 19 to $24 \mathrm{mmHg}$ in isolated measurements and/or cup/disc ratio $\geq 0.7$ in one or both eyes and/or asymmetry of cup/disc ratio $\geq 0.3$ and a normal visual field. Each daily curve of intraocular pressure comprised five to seven IOP measurements with Goldmann applanation tonometer at 9:00 a.m., 12:00 p.m., 3:00 and/or 6:00 and 10:00 p.m. and/or 12:00 a.m. and in the following day morning at 6:00 a.m. in supine position in bed and in darkness with Perkins tonometer before the patient had stood up. Only the daily curves of intraocular pressure that presented an intraocular pressure peak (difference between the higher and the lesser intraocular pressure value) $>6 \mathrm{mmHg}$ were analyzed. In these daily curves, the average intraocular pressure and the standard deviation were calculated. The average intraocular pressure and standard deviation values were compared with the normal superior limits: average + two standard deviation of average intraocular pressure and standard deviation of intraocular pressure daily curve from normal patients of the same age group. Daily curves were considered abnormal when their average intraocular pressure and standard deviation values were above the normal superior limits. Secondary and congenital glaucoma were excluded.

Results: Daily curves of intraocular pressure of 565 eyes were analyzed; 361 suspected eyes and 204 eyes with primary open-angle glaucoma. In suspects, $64.3 \%$ presented an intraocular pressure peak at 6:00 a.m. in bed. In primary open-angle glaucoma, $68.6 \%$ presented an intraocular pressure peak at 6:00 a.m. in bed. In 5.3\% of the suspects and in 5.9\% of primary open-angle glaucoma patients, the daily curve of intraocular pressure profile was inverted (lesser intraocular pressure at 6:00 a.m.).

Conclusion: Intraocular pressure peaks at 6:00 a.m. were responsible for the diagnosis of preperimetric glaucoma in $64.3 \%$ of suspects and revealed inadequate intraocular pressure control in $68.6 \%$ of eyes with primary openangle glaucoma. The daily curve of intraocular pressure including the intraocular pressure measurement at 6:00 a.m. in bed and in darkness is of vital importance in doubtful cases in order to confirm the diagnosis of preperimetric glaucoma in suspects as well as for the adequate intraocular pressure evaluation of antiglaucomatous treatment.

Keywords: Intraocular pressure/physiology; Ocular hypertension; Glaucoma, open-angle/diagnosis; Circadian rhythm/physiology; Tonometry, ocular; Monitoring, physiologic

\section{RESUMO}

Objetivo: Avaliar a importância da medida da pressão intraocular (Po) às $6 \mathrm{~h}$ noleito e no escuro para o diagnóstico de glaucoma pré-perimétrico e controle do tratamento do glaucoma primário de ângulo aberto (GPAA).

Métodos: Análise retrospectiva da curva diária de pressão intraocular (CDPo) de suspeitos e glaucomatosos com perda de campo visual em tratamento. Suspeitos: Po de 19 a $24 \mathrm{mmHg}$ e/ou relação escavação/disco (E/D) $\geq 0,7$ num olho ou nos dois olhos e/ou assimetria de E/D $\geq 0,3$ e campo visual normal. Cada curva diária de pressão intraocular: cinco a sete medidas (tonômetro de Goldmann) feitas às 9:00, 12:00, 15:00 e/ou 18:00 e 22:00 e/ou 24:00 h e na manhã seguinte às 6:00 h (tonômetro de Perkins) com o paciente em decúbito dorsal e no escuro, antes de levantar-se. Analisadas apenas as curvas diária de pressão intraocular que apresentavam pico de Po (diferença entre o maior e o menor valor de Po) $>6 \mathrm{mmHg}$. Nessas curvas diária de pressão intraocular, calculamos a pressão média (Pm) e a variabilidade (V) e as comparamos com os limites superiores da normalidade: média + dois desvios-padrões da Pm e da V obtidos no Serviço de pacientes normais do mesmo grupo etário. As curvas diária de pressão intraocular com Pm e/ou Vacima dos limites superiores da normalidade foram consideradas anormais. Excluídas: CDPos de glaucomas secundário e congênito.

Resultados: Analisadas curvas diária de pressão intraocular de 565 olhos: 361 olhos de suspeitos e 204 de glaucomatosos. Picos de Po às 6:00 h foram encontrados em $64,3 \%$ dos suspeitos e em $68,6 \%$ dos glaucomatosos. Em 5,3\% dos suspeitos e em 5,9\% dos glaucomatosos, o perfil da CDPo foi invertido (menor valor da Po às 6:00 h).

Conclusão: Picos de Po às 6:00 h foram responsáveis pelo diagnóstico de glaucoma pré-perimétrico em $64,3 \%$ dos suspeitos e revelaram inadequado controle da Po em $68,6 \%$ dos ol hos glaucomatosos. Em casos duvidosos, a medida da Po às 6:00 h no leito e no escuro com um tonômetro de aplanação é indispensável para confirmar o diagnóstico de glaucoma pré-perimétrico e para a adequada avaliação do tratamento antiglaucomatoso.

Descritores: Pressão intraocular/fisiologia; Hipertensão ocular; Glaucoma de ângulo aberto/diagnóstico; Ritmo circadiano/fisiologia; Tonometria ocular;Monitorização fisiológica

\footnotetext{
Work carried out at Glaucoma Service, Hospital São Geraldo, Universidade Federal de Minas Gerais - UFMG - Belo Horizonte (MG), Brazil.

${ }^{1}$ Physician, Ophthalmology Department, Faculdade de Medicina, Universidade Federal de Minas Gerais - UFMG - Belo Horizonte (MG), Brazil.

2 Undergraduate student, Faculdade de Medicina, Universidade Federal de Minas Gerais UFMG - Belo Horizonte (MG), Brazil; Scholar of Scientific Initiation (PIBIC - CNPq).

None of the authors had proprietary interest in the development and marketing of any products mentioned in the article.

Correspondence address: Sebastião Cronemberger. Rua Martim de Carvalho, 410/ 501 - Belo Horizonte (MG) - CEP 30190-090 - E-mail: cronem@task.com.

Recebido para publicação em 05.07.2009

Última versão recebida em 18.04.2010

Aprovação em 29.06.2010
}

\section{INTRODUCTION}

T he current consensus states that the elevated intraocular pressure $(\mathrm{IOP})$ is the main risk factor for the development and the progression of primary open-angle glaucoma (POAG) $)^{(1-4)}$. Recently, it was demonstrated in the Advanced Glaucoma Intervention Study (AGIS) that long-term IOP fluctuation is associated with a progression of visual field loss in patients with low mean IOP but not in patients with high mean $I O P^{(5)}$.This fact has been well- 
known since Maklakov's research at the beginning of the $20^{\text {th }}$ century using a Maklakov applanation tonometer ${ }^{(6)}$.

It is widely recognized that the IOP varies throughout the twenty-four hours. Also, IOP reduction is the only goal in the treatment of glaucoma ${ }^{(1-5)}$. Despite this, only a few ophthalmologists carry out a rigorous investigation of IOP using the daily curve of intraocular pressure (DCPO) by taking the IOP measurement at 6:00 a.m. with the patient in a supine position in bed and in darkness before the patient had stood up ${ }^{(7-9)}$.

For some authors, the DCPo with the IOP measurement taken with an applanation tonometer at 6:00 a.m. in a supine position in bed and darkness has great importance to establish the diagnosis of suspected patients and the assessment of IOP control of glaucomatous patients ${ }^{(10-14)}$.

However, other authors have studied the diurnal IOP variations by diurnal curves (DC) with 4-6 IOP readings generally taken between 8 a.m. and 6:30 p.m. of the same day ${ }^{(13)}$.

Thiel (1925) was the first to report, without the benefit of the Goldmann applanation tonometer (GAT), that the IOP is more elevated in the morning between 5:00 and 7:00 a.m. before the patient stands up $^{(14)}$. He reported that the nocturnal IOP elevation is caused by the supine position that leads to cerebral and ocular venous stasis that reduces the aqueous outflow ${ }^{(14)}$.

Some authors did the DCPO with the IOP measurement taken at 6:00 a.m. in a supine position but they used the TonoPen or the pneumotonometer to measure the $\operatorname{IOP}^{(10,15)}$.

This paper evaluates the importance of measuring the IOP at 6:00 a.m. in supine position in bed and in darkness using an applanation tonometer before the patient has stood up in the management of suspected and glaucomatous patients.

\section{METHODS}

A retrospective analysis of the DCPo of suspects and glaucomatous patients was performed. Suspects presented an IOP, without medication, ranging from 19 to $24 \mathrm{mmHg}$ in an isolated measurement and/or cup/disc ratio (C/D) equal to or higher than 0.7 in one or both eyes and/or an asymmetry of C/D equal to or higher than 0.3 and a normal visual field. In suspects, the DCPos were carried out for diagnostic purposes. In glaucomatous patients, who presented a C/D ratio equal to or higher than 0.7 and a typical visual field loss, the DCPos were performed to assess the effectiveness of antiglaucomatous treatment in reducing the IOP. Glaucoma progression was not evaluated. All glaucomatous patients were using antiglaucomatous medications, such as prostaglandin analogs, $\beta$-blockers, $\alpha$-agonists or topic carbonic anhydrase inhibitors when admitted. Each DCPo consisted from five to seven IOP measurements performed with GAT at 9:00 a.m. and 12:00 p.m. and at 3:00 and/or 6:00 and 10:00 p.m. and/or 12:00 a.m. and in the morning of the following day at 6:00 a.m. with Perkins tonometer with the patient in a supine position in bed and in darkness and before he or she had stood up. IOP measurements were performed by two authors (SC and NC). Only the DCPos that presented an IOP peak (difference between the higher and the lesser IOP value) superior to $6 \mathrm{mmHg}$ (abnormal IOP variation ${ }^{(16)}$ ) were considered. In these DCPos, the average IOP (Pm) and the standard deviation (variability - V) were calculated. Pm and $V$ values were compared with the normal superior limits: average + two standard deviation of Pm and average + two standard deviation of $V$ of the DCPo from normal patients of the same age group available in our service ${ }^{(12)}$. The DCPos were considered abnormal when their values of $\mathrm{Pm}$ and/or $\mathrm{V}$ were above the normal superior limits (Table 1). The DCPos of nonPOAG were excluded.

\section{RESULTS}

Three hundred and thirty-one patients were enrolled (21.2\%), representing the DCPos of 565 eyes equaling 206 (62.2\%) suspects (361 eyes) and 125 (37.8\%) POAG cases (204 eyes). We excluded 1229 (78.8\%) out of the 1560 DCPos analyzed because they did not fill the inclusion criteria. Among the suspects, $64.3 \%$ of the eyes presented abnormal Pm and/or $V$ when compared to those of the DCPo from normal patients of the same age group ${ }^{(12)}$. This percentage of abnormal Pm and/or $V$ value(s) was due to an abnormal IOP peak at 6:00 a.m. in supine position in bed and in darkness (Table 2). Therefore, based on the abnormal values of $\mathrm{Pm}$ and/or $\mathrm{V}$ and the normal result of the visual field, we definitively confirmed the diagnosis of preperimetric glaucoma in almost 2/3 of the suspects by measuring the IOP at 6:00 a.m. In glaucomatous patients, $68.6 \%$ of the eyes presented an abnormal Pm and/or $\mathrm{V}$ in the DCPo due to an abnormal IOP peak at 6:00 a.m. (Table 2). These data certainty revealed that these glaucomatous patients presented an inadequate IOP control. Moreover, in $5.3 \%$ of the suspects and in $5.9 \%$ of the glaucomatous, the DCPo profile revealed inverted values (lesser IOP value at 6:00 a.m.).

\section{DISCUSSION}

POAG is a challenging disease in which the elevated IOP is the primary risk factor. Taking into account that up to now the only treatment for that optic neuropathy is IOP reduction, it is clear that a rigorous IOP investigation should be mandatory. Papers about DCPo have been published for many years ${ }^{(8-12)}$. However, the majority of authors have studied the variations of the DC with 4-6 IOP readings generally taken between 8 a.m. and 6:30 p.m. of the same day ${ }^{(13)}$. Some authors have done the DCPo including the IOP measurement at 6:00 a.m. in supine position, but using the TonoPen or pneumotonometer ${ }^{(15)}$. TonoPen is an electronic tonometer and the pneumotonometer is an indentation tonometer and, therefore, neither are goldstandard instruments for IOP assessment because their reliability is variable ${ }^{(17-18)}$. The OBF-pneumotonometer and the TonoPen can register false values because they are more influenced by corneal thickness than the GAT ${ }^{(17-18)}$. The pneumotonometer is affected by ocular rigidity and the TonoPen tends to underestimate Goldmann's IOPs in patients with IOP equal to or greater than $30 \mathrm{mmHg}$.

Some authors, using the pneumotonometer, found that the nocturnal supine IOP (11:00 p.m. - 7:00 a.m.) was a little lower than the diurnal upright IOP (7:00 a.m. - 11:00 p.m.), resulting in the diagnosis of 24 untreated early glaucomatous patients ${ }^{(15)}$. In the present paper, in which only applanation tonometers (GAT and Perkins) were used, opposite results were obtained.

Other authors analyzed 690 DC of the right eye out of a total of 2272 DC obtained from 1178 patients. They reported

Table 1. Normal superior limits (average + two standard deviations) of the average IOP (Pm) and of the $V$ of the DCPo in normal patients according to their age $\mathrm{e}^{(12)}$

\begin{tabular}{lccc}
\hline Age Group & N & Pm & V \\
\hline 15 to 25 & 24 & 14.62 & 2.28 \\
26 to 35 & 22 & 15.93 & 2.28 \\
36 to 45 & 20 & 16.66 & 2.63 \\
46 to 58 & 20 & 16.92 & 2.22 \\
\hline
\end{tabular}

$\mathrm{DCPO}=$ diurnal curve of intraocular pressure; $\mathrm{Pm}=$ average intraocular pressure; $\mathrm{V}=$ standard deviation; $\mathrm{N}=$ number of eyes

${ }^{12}$ Calixto NS. 
Table 2. IOP Peak time ( $\triangle \mathrm{OP}>6 \mathrm{mmHg}$ ) of $331 \mathrm{DCP} o$ ( 565 eyes)

\begin{tabular}{|c|c|c|c|c|c|c|c|c|c|}
\hline Diagnosis & IOP Peak & 6:00 a.m. (bed) & 9:00 a.m. & 12:00 p.m. & 3:00 p.m. & 6:00 p.m. & 10:00 p.m. & 2:00 a.m. & Total \\
\hline Suspects & N & $\begin{array}{c}232 \\
64.3 \%\end{array}$ & $\begin{array}{c}99 \\
27.4 \%\end{array}$ & $\begin{array}{c}16 \\
4.5 \%\end{array}$ & $\begin{array}{c}4 \\
1.1 \%\end{array}$ & $\begin{array}{c}5 \\
1.4 \%\end{array}$ & $\begin{array}{c}1 \\
0.3 \%\end{array}$ & $\begin{array}{c}4 \\
1.1 \%\end{array}$ & $\begin{array}{r}361 \\
100 \%\end{array}$ \\
\hline POAG & N & $\begin{array}{c}140 \\
68.6 \%\end{array}$ & $\begin{array}{c}31 \\
15.2 \%\end{array}$ & $\begin{array}{c}17 \\
8.3 \%\end{array}$ & $\begin{array}{c}3 \\
1.5 \%\end{array}$ & $\begin{array}{c}7 \\
3.4 \%\end{array}$ & $\begin{array}{c}2 \\
1.0 \%\end{array}$ & $\begin{array}{c}4 \\
2.0 \%\end{array}$ & $\begin{array}{r}204 \\
100 \%\end{array}$ \\
\hline Total & N & $\begin{array}{c}372 \\
65.8 \%\end{array}$ & $\begin{array}{c}130 \\
23.0 \%\end{array}$ & $\begin{array}{c}33 \\
5.9 \%\end{array}$ & $\begin{array}{c}7 \\
1.2 \%\end{array}$ & $\begin{array}{c}12 \\
2.1 \%\end{array}$ & $\begin{array}{c}3 \\
0.5 \%\end{array}$ & $\begin{array}{c}8 \\
1.4 \%\end{array}$ & $\begin{array}{r}565 \\
100 \%\end{array}$ \\
\hline
\end{tabular}

$\mathrm{N}=$ number of eyes; $\mathrm{POAG}=$ primary open-angle glaucoma

that in $40 \%$ of the cases, the highest IOP was found at the earliest morning measurement with $65 \%$ of peaks occurring before noon ${ }^{(13)}$. Again, our data were completely different.

There are more differences between the findings of the present paper and those of the works above ${ }^{(13,15)}$. First, to the best of our knowledge, this paper analyzed the greatest sample of DCPos in which the IOP of suspected and glaucomatous eyes was measured at 6:00 a.m. with an applanation tonometer (Perkins) in bed and in darkness before the patient had stood up. Second, besides the important finding that the highest percentage of IOP peaks occurs at 6:00 a.m. in suspected (64.3\%) and glaucomatous patients under inadequate treatment (65.8\%), two other findings must be emphasized. Firstly, the relatively low percentage (23\%) of IOP peaks at 9:00 a.m. and secondly, the even lower percentage of IOP peaks at the end of the morning (0.01\% at 11:00 a.m.) and during normal office hours from 12:00 to 6:00 p.m. (8.8\%). This is, precisely, the most common time period when most ophthalmologists perform the IOP measurements.

Undetected IOP peaks at 6:00 a.m. in bed and darkness can be responsible for the failure to substantiate an early diagnosis of preperimetric glaucoma. Also, some authors reported that IOP peaks can be responsible for glaucoma progression in some patients $s^{(8,19-20)}$. In this paper, the glaucoma progression was not evaluated.

To assure early glaucoma diagnosis and adequate IOP control in glaucoma patients, we always perform a DCPo with at least five IOP measurements including the IOP taken at 6:00 a.m. (at the hospital or home's patient[H1]) using the Perkins tonometer before the patient has stood up.

In literature, a few papers show similar results to those of this paper ${ }^{(8-9,14,19)}$. In the past, one author reported that in 140 untreated glaucomatous eyes, $60 \%$ of the IOP peaks occurred at 6:00 a.m. in spite of the fact that the IOP measurement had been recorded with a certified Schiötz tonometer and a $5.5 \mathrm{gm}$. weight ${ }^{(8)}$. It is not clear in that paper if the IOP at 6:00 a.m. was measured in bed in a supine position. A Brazilian paper made a comparison between the DCPo and DC performed by seven residents about IOP peak detection and the verification of the influence of postural variation on 6:00 a.m. measurement ${ }^{(11)}$. In DC, they considered the IOP measurements at 9:00 a.m. - noon - 3:00 p.m. - 6:00 p.m. At 6:00 a.m., IOP measurements were performed in the dark, with patients in supine position, using Perkins tonometer. Then, another measurement was taken with GAT and these same patients were seated. Mean IOP and IOP peaks (IOP $\geq 21 \mathrm{mmHg}$ ) in the DCPo and DC were compared, as well as the time when the peaks occurred. The comparison showed that mean IOP was higher at 6:00 a.m. when taken in bed. The DC was unable to detect respectively $60.42 \%$ and $88.24 \%$ of IOP peaks in 68 glaucomatous and 57 suspected eyes $^{(11)}$. Another paper also demonstrated that the 24-hour IOP peak was higher than the peak noted during previous office visits in $40(62 \%)$ out of 64 eyes $^{(20)}$. The IOP peak was recorded outside of office hours in at least 1 eye in 22 (69\%) out of 32 patients ${ }^{(20)}$. Those authors suggested that in glaucoma patients with advanced disease or with progression that is disproportionate to known IOP measurements, 24-hour IOP monitoring can reveal higher peaks and wider fluctuation of IOP than those found during typical office hours, measured either in multiple office visits or repeatedly during a single day ${ }^{(20)}$.

In one study of 16 patients with normal pressure glaucoma suspicion, we found an abnormal DCPo in 14 (87.5\%) of them. Only two patients had normal DCPo. However, one patient presented severe circulation alterations of both internal carotid arteries and the other presented pathological tonographic coefficients ${ }^{(21)}$.

As demonstrated in one paper dating from $1925^{(14)}$, along with others ${ }^{(11,21)}$, the data of this paper emphasize that is impossible to establish the diagnosis of normal-tension glaucoma without a complete and adequate IOP evaluation with its measurement taken with an applanation tonometer (Perkins) at 6:00 a.m. in bed and in darkness before the patient stood up. A substantial variation in the IOP is common in these patients, truly characterizing an abnormality which was not registered ${ }^{(19)}$. Likewise, all epidemiological studies for evaluation of the diagnosis and treatment of this disease that do not take into account the IOP variations are incomplete and, therefore, unable to demonstrate the true role of the IOP in suspected and glaucomatous patients.

In the most recent paper, the authors analyzed retrospectively the 24-hour IOP curves of 29 healthy subjects (10 young adults, 19 elderly) and 30 patients with untreated glaucoma ${ }^{(22)}$. IOP measurements were taken at 9 a.m.; 12, 3, 6, and 9 p.m.; and 12, 3, and 6 a.m., both in supine and sitting (GAT) positions. During the night, IOP measurements were made with an electronic tonometer (Tonopen $\mathrm{XL}$ ) when the patient was in supine position and with a GAT when the patient was seated in front of a slit lamp. Peak, mean, and fluctuation of 24-hour IOP curves were compared with office-hour measurements obtained in subjects in the sitting position alone and with combined pressures obtained in the sitting and supine positions (four measurements in each body position from 9 a.m. to 6 p.m.). The percentage of subjects with estimates of all IOP parameters within a cutoff of \pm 1 (peak and mean) and $\pm 2 \mathrm{mmHg}$ (fluctuation) was calculated. They reported that office-hour sitting measurements correctly identified peak, mean, and IOP fluctuation in $10 \%$ of the young adults, $32 \%$ of the elderly control subjects, and $20 \%$ of the patients with glaucoma, whereas the combination of supine and sitting measurements correctly identified them in 30\%, $85 \%$, and $46 \%$ of the cases, respectively. It is noteworthy that office-hour measurements did not characterize any 24 -hour parameter in $20 \%$ of patients with glaucoma. The authors recommended that supine and sitting IOP data be collected during office hours, at least in patients with abnormal tonometric functional behavior (i.e., unexplained progression) to reduce their need for 24-hour monitoring. We are in total disagreement with these authors 
because: 1. The IOP evaluation in supine and sitting position during office hours is less reliable and more time-consuming than the DCPo we have done including the IOP measurement taken at 6:00 a.m.; 2.Tonopen, used in that paper, can register false values because it is more influenced by corneal thickness than the $\mathrm{GAT}^{(18)}$; 3 . The change of patient's position from supine to sitting alters the behavior of the IOP in POAG and normal tension glaucoma patients, as well as in normal eyes. However, the raise in IOP neither is significant when compared among the 3 groups nor is consistent with visual field defects ${ }^{(23)}$.

Unfortunately, most ophthalmologists manage their glaucomatous patients on the basis of sporadic IOP measurements that are taken during regular office hours, generally in the afternoon.

We think that is meaningless to follow suspected or glaucomatous patients under treatment performing the IOP measurements only in the afternoon.

\section{CONCLUSION}

On average, (65.8\%) of the IOP peaks in suspects and glaucomatous patients with inadequate treatment were discovered by measuring the IOP at 6:00 a.m. in supine position in bed and in darkness before the patient stood up with an applanation tonometer. Also, at 6:00 a.m., on average, 5.6\% of the eyes of suspects and glaucomatous patients with inadequate IOP control presented the lesser IOP value.

In dubious cases, in order to correctly diagnose preperimetric glaucoma in suspects as well as for the adequate evaluation of clinical treatment of POAG, the DCPo correctly performed is of vital importance.

\section{REFERENCES}

1. The Advanced Glaucoma Intervention Study (AGIS). 7. The relationship between control of intraocular pressure and visual field deterioration. The AGIS Investigators. Am J Ophthalmol.2000;130(4):129-40. Comment in: Am J Ophthalmol. 2000; 130(4):490-1.

2. Kass MA, Heuer DK, Higginbotham EJ, Johnson CA, Keltner JL, Miller JP, et al. The Ocular Hypertension Treatment Study: a randomized trial determines that topical ocular hypotensive medications delays or prevents the onset of primary openangle glaucoma. Arch Ophthalmol. 2002;120(6):701-13; discussion 829-30. Comment in: Arch Ophthalmol. 2004;122(7):1088-9; author reply 1089. Arch Ophthlamol. 2003 121(7):1070; author reply 1070.

3. Heijl A, Leske MC, Bengtsson B, Hyman L, Bengtsson B, Hussein M; Early Manifest Glaucoma Trial Group. Reduction of intraocular pressure and glaucoma progression: results from the Early Manifest Glaucoma Trial. Arch Ophthalmol. 2002:120(10): 1268-79. Comment in: Arch Ophthalmol. 2002;120(10):1371-2. JAMA. 2002;288(20): 2607-8. Optom Vis Sci. 2002;79(12):741-2.
4. Bergea B, Bodin L, Svedbergh B. Impact of intraocular pressure regulation on visual fields in open-angle glaucoma. Ophthalmology. 1999;106(5):997-1005; discussion 1004-5.

5. Caprioli J, Coleman AL. Intraocular pressure fluctuation a risk factor for visual field progression at low intraocular pressures in the advanced glaucoma intervention study. Ophthalmology. 2008;115(7):1123-9. Comment in: Ophthalmology. 2009; 116(4):817.

6. Maklakov A. L'ophtalmotonometrie. Arch Ophtalmol. 1885:5:159.

7. Musch DC, Lichter PR, Guire KE, Standardi CL. The Collaborative Initial Glaucoma Treatment Study: study design, methods, and baseline characteristics of enrolled patients. Ophthalmology. 1999:106(4):653-62.

8. Drance SM. The significance of the diurnal tension variations in the normal and glaucomatous eyes. Arch Ophthalmol. 1960;64:494-501.

9. Sampaolesi R, Calixto N, De Carvalho CA, Reca R. Diurnal variation of intraocular pressure in healthy, suspected, and glaucomatous eyes. Med Problem Ophthalmol. 1968;74:1-23.

10. Hughes E, Spry P, Diamond J. 24-hour monitoring of intraocular pressure in glaucoma management; a retrospective review. J Glaucoma. 2003;12(3):232-6.

11. Rodrigues LD, Silva MR, Schellini AS, Jorge EN. Picos de pressão intraocular: comparação entre curva tensional diária, minicurva e medida da pressão intraocular às 6 horas. Arq Bras Oftalmol. 2004;67(1):127-31.

12. Calixto NS. Pressão intraocular, curva diária de pressão intraocular, rigidez parietal e coeficientes tonográficos (Médias de normalidade em diferentes grupos etários) [tese]. Belo Horizonte; Universidade Federal de Minas Gerais; 1967. p.51.

13 David R, Zangwill L, Briscoe D, Dagan M, Yagev R, Yassur Y. Diurnal intraocular variations: an analysis of 690 diurnal curves. Br J Ophthalmol. 1992;76(5):280-3.

14 Thiel R. Die physiologischen und experimental erzeutgen Schankungen des intraocularen Druckes im gesundem und glaukomatosen. Auge Arch Augenheilk. 1925:96:331-54

15. Liu JH, Zhang X, Kripke DF, Weinreb RN. Twenty-four-hour intraocular pattern associated with early glaucomatous changes. Invest Ophthalmol Vis Sci. 2003; 44(4):1586-90

16. Duke-Elder S. The phasic variations in the ocular tension in primary glaucoma. Am J Ophthalmol. 1952;35(1):1-21

17. Gupta V, Sony P, Agarwal HC, Sihota R, Sharma A. Inter-instrument agreement and influence of central corneal thickness on measurements with Goldmann, pneumotonometer and noncontact tonometer in glaucomatous eyes. Indian J Ophthalmol. 2006;54(4):261-5

18. Amaral WO, Teixeira RM, Alencar LM, Cronemberger S, Calixto N. [Central and peripheral corneal thickness: influence on the iop measurement by Tonopen]. Arq Bras Oftalmol. 2006;69(1):41-5. Portuguese.

19. Asrani S, Zeimer R, Wilensky J, Gieser D, Vitale S, Lindenmuth K. Large diurnal fluctuations in intraocular pressure are an independent risk factor in patients with glaucoma. J Glaucoma. 2000;9(2):134-42. Comment in: J Glaucoma. 9(6):487-8.

20. Barkana Y, Anis S, Liebmann J, Tello C, Ritch R. Clinical utility of intraocular pressure monitoring outside of normal office hours in patients with glaucoma. Arch Ophthalmol. 2006:124(6):793-7.

21. Calixto N, Meira DM, Cronemberger S. Estudo de pacientes com suspeita diagnóstica de glaucoma de pressão normal. Rev Bras Oftalmol. 1997;56(11):823-35.

22. Fogagnolo P, Orzalest N, Ferreras A, Rossetti L. The circadian curve of intraocular pressure: can we estimate its characteristics during office hours? Invest Ophthalmol Vis Sci. 2009;50(5):2209-15

23. Meirelles SHS, Mathias CR, Brandão G, Frota ACA, Yamane R. Influência da postura na pressão intraocular e nos defeitos de campo visual no glaucoma primário de angulo aberto e glaucoma de pressão normal. Rev Bras Oftalmol. 2008;67(1):19-24.

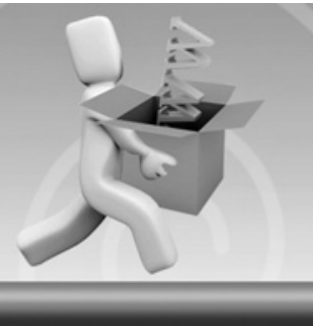

